\title{
RESEARCH ON THE DYNAMICS OF LITHUANIAN STATE REVENUE AND PREFERENCES FOR EXPENDITURE ALLOCATION
}

\author{
Ilona Skačkauskienė \\ Department of Social Economics and Management, Vilnius Gediminas Technical University, \\ Sauletekio al. 11, LT-10223 Vilnius, Lithuania \\ E-mail: ilona.skackauskiene@.vgtu.lt \\ Received 03 February 2013; accepted 21 March 2013
}

\begin{abstract}
The article analyses revenue and expenditure on the national budget of Lithuania and looks at their dynamics and structure. First, the paper is aimed at naming the main sources of revenue as well as the preferential areas of financing. Second, it is also sought to disclose the objective principles of allocating budget appropriation. To achieve the goal, the correlation between preferences in government activity and expenditure allocation was investigated. The conducted research employs ranging and correlational analysis. Since the formation of a bigger budget leads to an increased appropriation of all functional areas, structural data were analysed thus enabling to more soundly determine whether the distinction of a functional area, as the preferential one, has an influence on its greater significance in the overall system of the national budget. After making the study, no possibility of asserting that a distinction of the preferential functional area is related to its preferential financing exists. In order to summarize the obtained results, it could be claimed that the allocation of resources accumulated by the state would be more substantiated if we related it more with activity priorities of the Government. This would lead to higher objectivity when taking decisions on public administration.
\end{abstract}

Keywords: national budget, budget revenue and expenditure, expenditure allocation, financing preferences.

Reference to this paper should be made as follows: Skačkauskienè, I. 2013. Research on the dynamics of Lithuanian state revenue and preferences for expenditure allocation, Journal of Business Economics and Management 14(4): 806-817.

JEL Classification: H71, H72, G38.

\section{Introduction}

The current global economic crisis having a significant impact on the welfare of a number of different countries has caused many discussions (Butkevičius 2009; Gylys 2011; Stanikūnas 2010; Stiglitz 2009), stimulated rethinking policies in hand as well as encouraged the initiation of operative actions. In Lithuania, the budget policy was reviewed, tax rates (except personal income tax) were increased, some of tax reliefs were withdrawn, tax base was expanded and national appropriation as well as investment was decreased. 
At the current stage of the global economic crisis, nations have been seeking to recover welfare by directly affecting economy. One of the most significant means to achieve this effect is a budget, which is a prerequisite for a rational allocation of financial resources as well as for an efficient impact on social economic processes. The formation and implementation of the budget have a direct effect on citizens (e.g. through social support and care in hand, salaries of the employees of budgetary organizations and budget appropriations aimed at creating effective administrative mechanisms improving life quality of citizens) and business (e.g. direct purchasing of national goods and services, grants and subsidies for business). The effect is even more apparent knowing that in many countries a significant share of the national product - from $30 \%$ (e.g. Lithuania, Latvia) to $60 \%$ (e.g. Denmark, Belgium and Sweden) - is reallocated through the budget (EC 2011).

The topic of the budget has been investigated by many authors (Bivainis, Butkevičius 2003; Golenko-Ginzburg et al. 2006; Karkatsoulis 2010; Naraškevičiūte 2008; Rakauskienè, Chlivickas 2007, etc.). The present work, by analyzing the state revenue and expenditure of Lithuania, as well as determining the most significant peculiarities of their dynamics and structure, aims to disclose the correlation between priorities as declared by the government and the allocation of finance for them. In other words, it seeks for questioning if declaring some preferential area or activity is related to an increase in financing that area or activity. The effective management of the state comes along with a purposeful budget policy, clear and consistent activity priorities as well as their respective financing.

In order to carry out research, statistical, content, vertical, horizontal as well as correlation analyses were applied. In addition, a systematic approach, ranging and synthesis were employed.

\section{The main sources of revenue: dynamics and structure}

Systematic investigation into the national budget is impossible without analysing its constituent parts - revenue and expenditure. Usually, examination starts off by analyzing the part of revenue classified to structuralize budget data in different aspects to take necessary decisions. As classification according to the sources of revenue is widely used and performed in many countries, the International Monetary Fund (IMF), which seeks to enable a comparison of data, has prepared a finance statistics manual looking at the sources of tax revenue and non-tax revenue. In many countries, a predominant source of revenue is tax revenue generated from non-repayable obligatory transfer of money to the state, whereas other sources of revenue are pieced together into the heterogeneous group of revenue comprising: 1) social security transfers; 2) grants; 3) property revenue; 4) revenue from selling goods and services; 5) other different revenues (e.g. fines, delay charges, forfeit, etc.). Budget revenue is further investigated by partly following recommendations made by the finance statistics manual of IMF, i.e. both tax and non-tax revenues of the state budget are analyzed. However, in order to make a comparison of data, the latter group is examined in accordance with data classification as presented by the Department of Statistics to the Government of the Republic of Lithuania. 
In many countries, state expenditure on governmental public service functions is mostly covered by taxation, fees and other obligatory payments that all together constitute national revenue (Skačkauskienè 2012). Apparently, an increase in financing that meets social economic needs as well as maintaining the governmental apparatus leads to a demand for state revenue resources mainly formed by taxation. This is proved to be true by an increase in national budget revenues of many countries. For the period 2000-2010, a growth in the national budget revenue of Lithuania made $167 \%$ (the year 2008 , if compared to 2000 , witnessed a growth in $214 \%$ ), out of which $96 \%$ constituted tax revenue, and, in 2010, comprised $68 \%$ of state budget revenue (Table 1). In 2010, tax revenue (along with payments for social security) in Lithuania constituted $81 \%$. Meanwhile, in Great Britain, it amounted to $92 \%$, Latvia $-77 \%$, Poland $-85 \%$ and Germany $-90 \%$ of the total revenues (EU 2012).

Table 1. The national budget revenue of Lithuania (million litas)

\begin{tabular}{lccccccccccc}
\hline Year & 2000 & 2001 & 2002 & 2003 & 2004 & 2005 & 2006 & 2007 & 2008 & 2009 & 2010 \\
\hline Revenue & 8724 & 9276 & 10572 & 11360 & 13815 & 16490 & 19542 & 24048 & 27396 & 24284 & 23310 \\
\hline $\begin{array}{l}\text { Including tax } \\
\text { revenue }\end{array}$ & 8033 & 8105 & 8991 & 9723 & 11086 & 12900 & 15604 & 18629 & 21787 & 16463 & 15722 \\
\hline
\end{tabular}

The largest part of the tax revenue of the national budget derives from four major tax categories: value-added tax (VAT), excise tax, corporate income tax and personal income tax. A common characteristic of the Lithuanian tax system is high indirect tax rates. Starting from 2000 and up to the present, these taxes have constituted $50 \%$ of the total revenue of the national budget. The major part of the revenue of the state budget is composed of indirect taxes - VAT amounting to $30 \%$.

A smaller part of national budget revenue is composed of non-tax revenue that also comprise revenue on exploited state and municipal property, revenue on fines and forfreit and other non-tax revenues, as well as revenue on capital and the European Union support, which has become the source of revenue since Lithuania joined the European Union (EU) and attributed it to the state budget.

Within the analysed period, the non-tax revenue of the state budget increased by 11 times (or 999\%) and comprised 690522 thousand litas in 2000 and 7588224 thousand litas in 2010 (see Fig. 1) respectively. The increase was mainly caused by the EU support received since 2004 (apart form that, a growth would increase 3 times). For the same period, the EU support, which was the largest part of non-tax revenue, was increasing almost annually. However, regearding such growth, a tendency towards every other year can be traced and a significant increase can be noticed (45\% in 2005, 61\% in 2007 and $70 \%$ in 2009 respectively), whereas the rest of the years witnessed a growth in $8-9 \%$ (except for 2008, when revenue increased only by 314 thousand litas making $0.01 \%$, and in 2010 when revenue decreased by 582854 thousand litas and made $10 \%$ respectively). Every year, the rest of the non-tax revenues of the state budget may vary, i.e. one year they can be low, the following - can rise significantly and the one after the folowing - can decline again. This happens due to governmental decisions, e. g. on selling disposable property and increasing revenue in this way. 


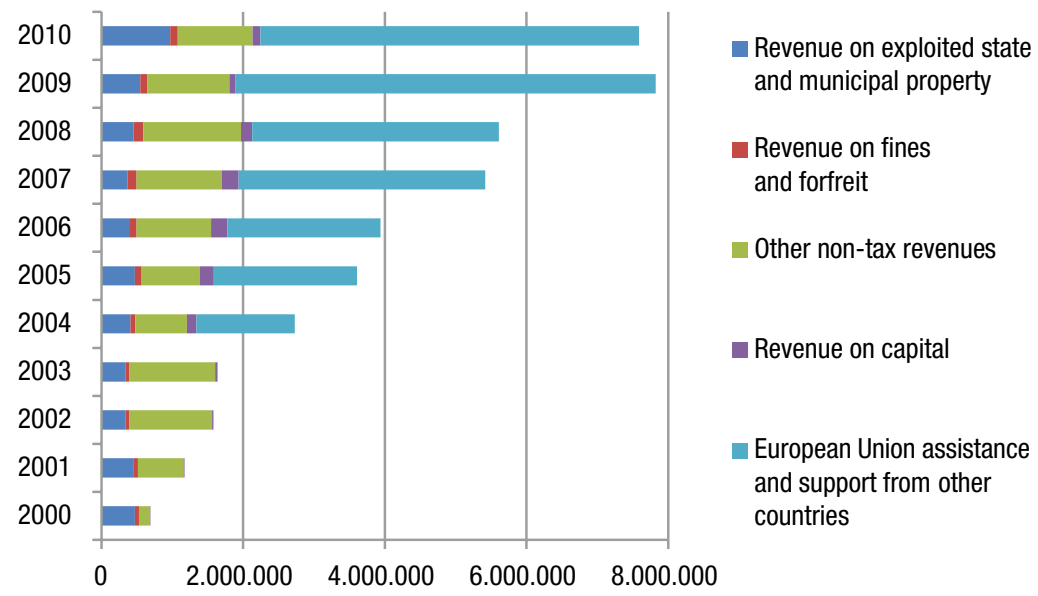

Fig. 1. The dynamics of the non-tax revenue of the state budget (thousand litas)

The conducted analysis of a growth in revenue relating it to an increase in expenditure disclosed that the percentage of national budget revenue increased more rapidly than expenditure for the period 2003-2005, whereas in 2006, a growth in expenditure exceeded the growth of revenue (see Fig. 2). In 2007, percentage increase in revenue again exceeded an increase in expenditure. Last year, the situation was similar and revenue was increasing more rapidly than expenditure. The most significant gap between the growth of revenue and expenditure was in 2009 ( $-10 \%$ points). Even though, in 2010, the difference between the growth of expenditure and revenue became smaller (to $-2 \%$ points), and the absolute expression of the budget deficit was the highest during the entire analyzed period and made 4.3 billion litas.

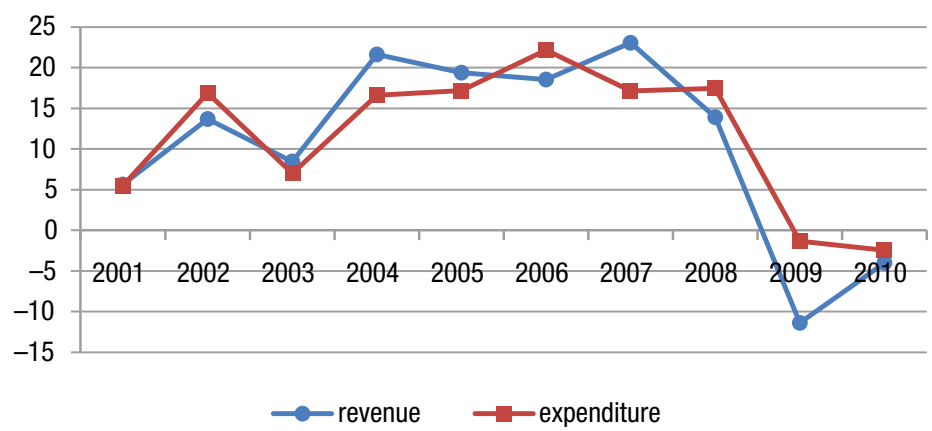

Fig. 2. The dynamics of percentage variation in revenue and expenditure of the state budget (on a comparative basis of the last year) 


\section{Preferences for allocating national budget resources}

In order to analyze preferences for allocating accumulated resources, the classification of Lithuanian state revenue and expenditure should be applied. The economic classification of revenue as well as the economic and functional classification of the expenditure of the budget is determined by the Ministry of Finance. The classification of state and municipal budget revenue and the expenditure of the Republic of Lithuania are approved by Order No 1K-184 of 3 July 2003 (replaced by Order No 1K-085 of 26 March 2010) of the Minister of Finance of the Republic of Lithuania. After conducting dynamic and structural analysis on data from the Lithuanian governmental sector, classification helps in determining the most important variation points as well as in crystallizing the areas of preferential activity. While carrying out research, the biggest attention was given to the analysis of appropriations based on functions. The analyzed data reflect the governmental budget policy. In order to do research, data from the Ministry of Finance on budget implementation in 2004-2010 were used (the classification of expenditure for the period 2000-2003 based on functions differs from the later years of the analyzed period). Therefore, only generalized analysis according to 3 major governmental functions, including expenditure on economic affairs, social sphere and other state functions, is feasible. This kind of analysis has also been performed by a number of other authors (Butkevičius, Bivainis 2009; Buškevičiūtè 2006; Rakauskienè 2006). Thus, in order to avoid a compilation only, this period and data from the Department of Statistics to the Government of the Republic of Lithuania are not analyzed (statistical record of data for the period 2004-2010).

During the investigated period, the expenditure of the national budget increased almost twice. A rapid growth in expenditure reflects the increasing significance of the budget policy seeking for the purposeful pursuit of a social-economic policy. For the period 2004-2010, the expenditure of the national budget was increasing by 2008 while and in 2009 and 2010, a decline in expenditure was identified. Given the economic situation of that period in Lithuania, i.e. a period of economic rise that lasted up to 2008 and economic downturn that started in 2009 due to the global financial crisis, it could be concluded that the Lithuanian budget policy had an insufficient effect. On the one hand, an increase in state expenditure during an economic rise stimulated inflation. On the other hand, an extremely significant decrease in state expenditure (along with other pursued measures, including taxes such as corporate income tax, VAT and excise taxes, for example, rising tariffs) during an economic downturn deepened deflationary processes - unemployment was increased, consumption and production declined (according to the Department of Statistics, unemployment reached $5.8 \%$ in 2008, and $17.8 \%$ in 2010, whereas expenditure on the total consumption reached 94867.7 million litas in 2008 and 80279.8 million litas in 2010 (Statistical Yearbook 2009-2011)).

When analyzing the expenditure of the national budget according to the functions distinguished into 10 categories, it could be noted that by absolute magnitude (on the basis of the year 2004), expenditure was increased for the needs of economic affairs, educa- 


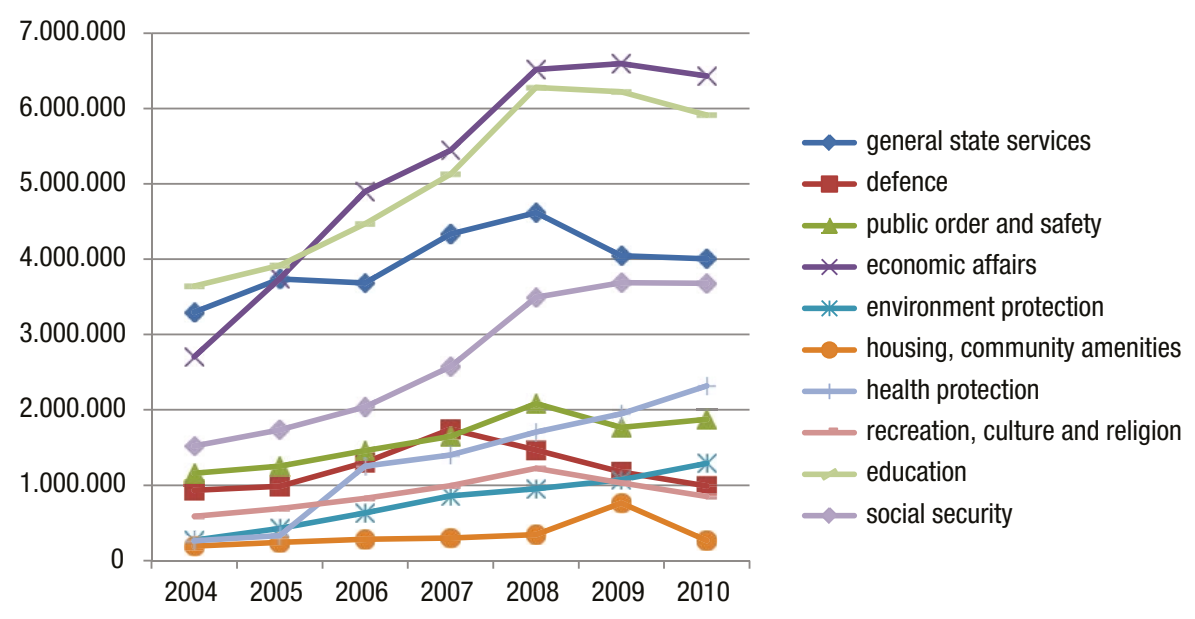

Fig. 3. The dynamics of state budget appropriation for the period 2004-2010 (thousand litas)

tion, health and social security $(3.73,2.27$ and 2.16 and 2.06 billion litas respectively) (see Fig. 3). As measured by percentage expression (on the basis of the year 2004), expenditure on health, environment, social security and economic affairs $(791 \%, 378 \%$, $142 \%$ and $138 \%$ respectively) were increased. The smallest part of national budget appropriations is allocated to housing, community amenities (arise in the value of appropriation, a relative indicator in this sphere shows increasing initiative), recreation, culture and religion.

In order to identify preferences for governmental activities, the relative values of expenditure structure should be analyzed. Generally, the largest part of appropriations in the whole structure of the expenditure of the national budget is allocated for economic affairs, education and general state services (see Fig. 4). For the analyzed period of 2004-2010, the most significant decrease in appropriations considering the general structure of expenditure was in the functions of general state services (from $23 \%$ in 2004 to $14 \%$ in 2010) and education (from $25 \%$ in 2004 to $21 \%$ in 2010). Meanwhile, there was an increase in economic affairs (from 19\% in 2004 to $23 \%$ in 2010) and health service (from $2 \%$ in 2004 to $8 \%$ in 2010) functions.

Attention should be given to the fact that the analysis of the expenditure of the national budget does not completely reflect an objective picture of financing the spheres of health service and social security. This is because the appropriations of this budget constitute from a quarter in 2004 and to a third in 2010 of the total financing of these areas. The other part is allocated to the budgets of the compulsory health insurance fund and social security fund. In general, taking into account the analyzed period, after combining data on all three budgets, an underwent increase in financing social security and health service makes more than 2.5 times, whereas a comparative weight of GDP grew by $10 \%$ points - from $15 \%$ of GDP in 2004 to $25 \%$ of GDP in 2010 . During the 

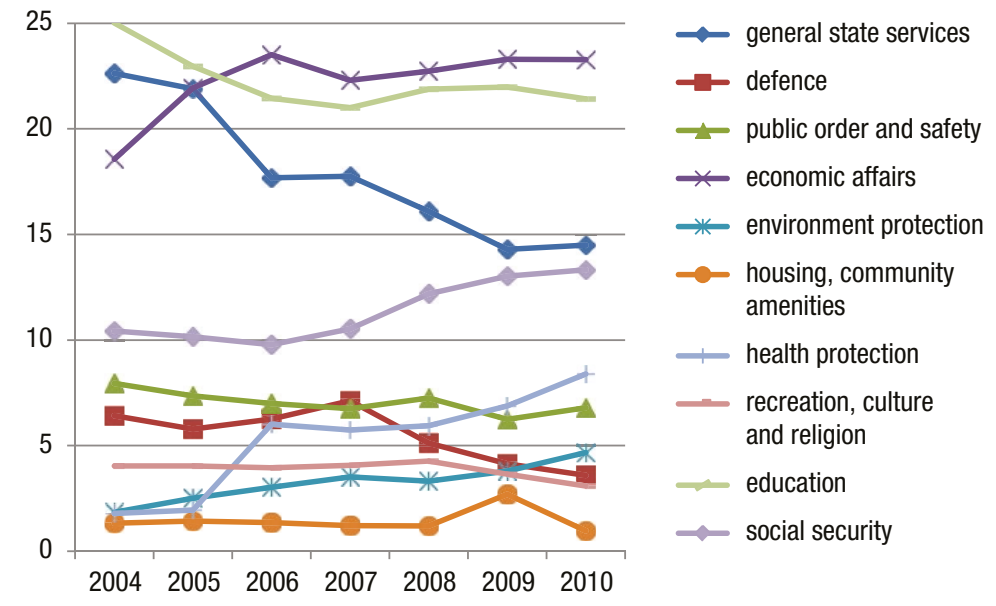

Fig. 4. The dynamics of the structure of the expenditure of the state budget for the period 2004-2010 (percentage)

economic downturn, bigger financing of social and health areas can be evaluated positively because these are the most susceptible to the consequences of the financial crisis. However, the biggest increase in financing these areas was felt during the economic rise, i.e. in 2006-2008 due to greater financing opportunities (bigger tax revenue accumulated) and additional financial commitments (e.g. maternity/paternity allowance). Such decisions increased the state expenditure and deficits of budgets, including the losing budget of the state social security fund since 2008 .

While looking at the financed fields (absolute sizes), it can be noted that in the analyzed period of 2004-2010 there was a slight alteration of preferences for allocating the resources of the Lithuanian Government. In the process of allocating national budget resources, financing the areas of education and economic affairs was on the focus (see Fig. 5).

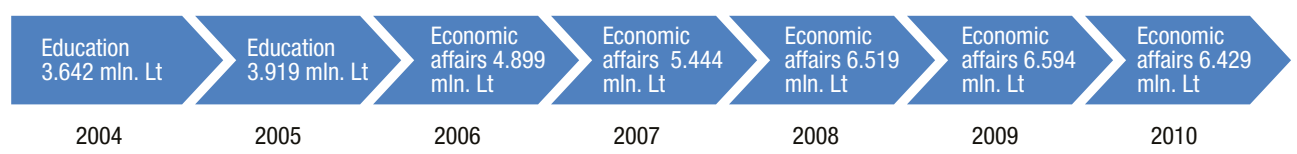

Fig 5. The areas that received the biggest financing (absolute expression) from the national budget

Meanwhile, when looking at a rise in financing from the national budget in the percentage expression, quite significant alteration can be traced, starting from general state services (2004) and finishing with environmental protection (2010) (see Fig. 6). Also, there was a significant rise in financing social security ( $75 \%$ in 2004$)$, economic affairs (38\% in 2005), defence (34\% in 2007), public order and safety ( $34 \%$ in 2008). 


\begin{tabular}{|c|c|c|c|c|c|c|}
\hline $\begin{array}{l}\text { General state } \\
\text { services } \\
(197 \%)\end{array}$ & $\begin{array}{l}\text { Environ } \\
\text { protect } \\
(58 \%)\end{array}$ & $\begin{array}{l}\text { Health } \\
\text { service } \\
(278 \%\end{array}$ & $\begin{array}{l}\text { Environm } \\
\text { protectior } \\
(36 \%)\end{array}$ & $\begin{array}{l}\text { Social } \\
\text { securit } \\
(36 \%)\end{array}$ & $\begin{array}{l}\text { lousing, } \\
\text { ommunit } \\
\text { menities }\end{array}$ & $\begin{array}{l}\text { Environment } \\
\text { protection } \\
(20 \%)\end{array}$ \\
\hline 2004 & 2005 & 2006 & 2007 & 2008 & 2009 & 2010 \\
\hline
\end{tabular}

Fig. 6. The areas that experienced the most significant increase in financing (percentage expression, on the basis of the last year) from the national budget for the period 2004-2010

In conclusion, as for the absolute expression, the most financed areas were economic affairs and education, whereas considering the percentage expression, the most significant increase in financing was in the areas of health service and environmental protection.

\section{Analysis of the correlation between governmental activity priorities and the allocation of expenditure in accordance with functions}

Additional information on investigation into preferences for the allocation of resources is provided by analyzing the priorities of governmental activity. Every year, the Government sets priorities in light of its activity, i.e. determines the areas given focus in a particular year (LRV 2004-2011). Usually, activity priorities are crystallized in accordance with the approved regulatory acts and in consideration of changes in the inner and outer environment. Furthermore, financial targets also have some impact. In order to determine them, macroeconomic forecasts, including blocks such as the balance of payments, national product, fiscal accounts as well as the monetary sector, are prepared. Information on these blocks is a tool for anticipating a growth in the state economy, fiscal deficit, exchange rates, inflation, current account balance, credit growth and public sector borrowing (Shah 2007). At the beginning of every year, the Government considers different activity priorities and, if needed, revises them.

The priorities of the Government of Lithuania are set in accordance with the Programme of the Government and Strategy for Progress. These priorities are considered by institutions when preparing or revising the programmes of their activity. Usually, 4-6 underlying activity courses or targets are set. Lithuania has followed this rule since 2007.

In order to determine the correlation between the priorities of governmental activities and financed areas, investigation was carried on in the following order: 1) the content of the functional classification of the priorities of governmental activity and expenditure; 2) priorities which, according to content characteristics, are categorized as a part of a functional financing area. It should be stressed that the priorities of governmental activity for the periods 2004-2005 and 2007-2009 are presented together, i.e. they are not distinguished taking into account each year of activity. Thus, an assumption that the priorities of governmental activity every year of a respective period remained the same was made; 3) points were attributed to functional financing areas. The rule of point attribution - from the highest (10 points) to the lowest (1 point) - was used. The same points were attributed to functional areas with the same priorities. Point attribution was done as follows: a functional area(s) that get(s) the highest number of priorities was 
identified. This field is given 10 points, whereas other fields are given the number of points in proportion to the number of priorities; 4) correlation analysis was done. In order to eliminate the impact of a bigger budget, the connection between the dynamics of the structure of a functional area and priorities was investigated.

After the analysis of content classifying the priorities and expenditure of governmental activity, activity priorities were attributed to the functional financing area. For example, preferred financing for the period 2004-2005 had to be given to general state services (attributed to the priority to consolidate Lithuania's influence on forming an economic policy of the European Union and decisions relevant to the country), defence (attributed to the priority to develop national defence such as NATO, a part of collective security and defence system), public order and safety (attributed to the priority to ensure public security and order), economic affairs (attributed to priorities to seek for sustainable development, ensure further improvement in business development conditions, develop a competitive agriculture sector, information and knowledge society, assure a growth in public transportation infrastructure), recreation, culture and religion (attributed to the priority to guarantee the promotion of national culture and healthiness), education (attributed to the priority to ensure the progress of education and science), social security (attributed to such priorities as to reduce unemployment and poverty). Thus, for the period 2004-2005, according to activity priorities declared by the Government, almost all areas were underlying. However, the biggest attention was given to implementing the function of economic affairs.

According to activity priorities as declared by the Government in 2004-2010, functional areas with preferred financing were determined (see Table 2). It was established that general state services, economic affairs and social security were the areas that, within the analyzed period, were annually identified as preferential.

Table 2. Preferential financing areas in accordance with priorities declared by the Government

\begin{tabular}{lccccccc}
\hline Functional areas & 2004 & 2005 & 2006 & 2007 & 2008 & 2009 & 2010 \\
\hline General state services & $\sqrt{ }$ & $\sqrt{ }$ & $\sqrt{ }$ & $\sqrt{ }$ & $\sqrt{ }$ & $\sqrt{ }$ & $\sqrt{ }$ \\
\hline Defence & $\sqrt{ }$ & $\sqrt{ }$ & $\sqrt{ }$ & $\sqrt{ }$ & $\sqrt{ }$ & $\sqrt{ }$ \\
\hline Public order and safety & $\sqrt{ }$ & $\sqrt{ }$ & $\sqrt{ }$ & $\sqrt{ }$ & $\sqrt{ }$ & $\sqrt{ }$ \\
\hline Economic affairs & $\sqrt{ }$ & $\sqrt{ }$ & $\sqrt{ }$ & $\sqrt{ }$ & $\sqrt{ }$ & $\sqrt{ }$ & $\sqrt{ }$ \\
\hline Environmental protection & & & & & & & \\
\hline Housing, community amenities & & & & $\sqrt{ }$ & $\sqrt{ }$ & $\sqrt{ }$ \\
\hline Health service & & & & $\sqrt{ }$ & $\sqrt{ }$ & $\sqrt{ }$ \\
\hline Recreation, culture and religion & $\sqrt{ }$ & $\sqrt{ }$ & $\sqrt{ }$ & $\sqrt{ }$ & $\sqrt{ }$ & \\
\hline Education & $\sqrt{ }$ & $\sqrt{ }$ & $\sqrt{ }$ & $\sqrt{ }$ & $\sqrt{ }$ & \\
\hline Social security & $\sqrt{ }$ & $\sqrt{ }$ & $\sqrt{ }$ & $\sqrt{ }$ & $\sqrt{ }$ & $\sqrt{ }$ \\
\hline
\end{tabular}


In order to determine the impact of activity priorities declared by the Government taking into account financing a respective functional area having the attributed priority, correlation analysis was done. It should be noted that, while forming a bigger budget, appropriations for all functional areas may also increase. Therefore, analysis was conducted using structural data that enable to more soundly determine whether the distinction of a functional area as the preferential one has any influence on its greater significance in the overall system of the state budget. The results of the performed analysis were the following:

1) the sizes of counted correlation coefficients were divided between 0.38 and 0.65 . It should be noted that in most of the cases, correlation coefficients between structural data and ascribed priorities are higher between absolute appropriation sizes and priorities; 2) agreeably to $t$ statistics, correlation is not significant - in all cases $-t<t_{k r}$, by significance level 0.05 . Thus, we cannot state that the distinction of the functional area as the preferential one is related to its preferential financing. It should be stressed that such result can be influenced by rather short time series $(n=7)$ : 1) since 2004, the functional classification of state expenditure has been changed; therefore, data from the previous years can be hardly compared; 2) even though in 2011 and 2012 activity priorities of the Government were provided, no statistical data on the pursued state budget were declared. In order to summarize the results of the conducted research, it could be claimed that the allocation of resources accumulated by the state would be more reasonable if we related it more with activity priorities of the Government. This would lead to higher objectivity when taking decisions on public administration.

\section{Conclusions}

1. One of the major preconditions for the successful existence and development of the state is the generation of budget revenue. As in many other countries, Lithuanian state budget mostly generates revenue from taxation (as much as 68\% in 2010). The main sources of taxation are value added (sales revenue), personal income and corporate income. It must be observed that the prevailing source of budget revenue in Lithuania is traditional - taxation; the bigest part of that is constituted by revenue generated from indirect taxes - VAT and excises. On the other hand, non-tax revenue is becoming a growing source of budget revenue and the biggest part of this revenue constitutes the European Union support given to Lithuania since 2004.

2. Following the examination of preferences for resources allocated by the Lithuanian Government for the period 2004-2010, slight changes can be noticed. When allocating the resources of the state budget, focus was given to financing the fields of education and economic affairs. It was noted that the analysis of state budget expenditure could not reflect the highest objectivity of financing health service and social security. These fields are also financed through the budget of the compulsory health insurance fund and the budget of the state social insurance fund. In general, considering the analysed period, after consolidating all data obtained from three budgets, it was noticed that financing social security and health service increased more than 2.5 times, whereas a 
comparative weight of GDP grew by $10 \%$ points. Although data on the consolidated budget are not published in Lithuania, some fragmentary information is provided in the Convergence programme. Publishing consolidated data would provide transparency to public finances, allow describing in greater detail the impact of the national fiscal policy on the economy and determine trends towards social economic development.

3. After carrying out research on the connection between the activity priorities of the Government and the allocation of expenditure in accordance with functions, the following points were determined: 1) general state services, economic affairs and social security appear as the areas that, within the analysed period, are annually identified as the preferential ones; 2) there is no possibility of asserting that the distinction of the functional area as the preferential one is related to its preferential financing. The allocation of resources generated by the Government would be more reasonable if relating it to the priorities of governmental activity. This would lead to higher objectivity when taking decisions on public administration.

\section{References}

Bivainis, J.; Butkevičius, A. 2003. Methodological aspects of evaluation of state budget programmes, Journal of Business Economics and Management 4(1): 53-61.

Butkevičius, A.; Bivainis, J. 2009. Nacionalinio biudžeto išlaidu planavimas [Planning of National Budegt Expenditure]. Vilnius: Technika. 246 p. ISBN 978-9955-28-469-7.

http://dx.doi.org/10.3846/1594-M

Butkevičius, A. 2009. Ar valdžios sprendimai atitinka žmonių lūkesčius? [If the Decisions of Governement links with Peoples Expectations?], Mokesčiu žinios [Tax news] 43(655): 11-12.

Buškevičiūtè, E. 2006. Viešieji finansai [Public finances]. Kaunas: Technologija. 442 p.

European Commission (EC). 2011. Taxation Trends in the European Union-Data for the EU Member States, Iceland and Norway. Luxembourg: Publications Office of the European Union. $422 \mathrm{p}$.

European Union (EU). 2012. Statistics in Focus, No 2 [online], [cited 21 November 2012]. Available from Internet: http://epp.eurostat.ec.europa.eu/portal/page/portal/publications/collections/sif_dif/sif

Gylys, P. 2011. Antieconomy, economy crisis and crisis of economics, Ekonomika [Economics] 90(4): 18-33.

Golenko-Ginzburg, D.; Laslo, Z.; Ben-Yair, A.; Baron, A. 2006. Optimizing budget allocation among project activities, Journal of Business Economics and Management 7(1): 17-20.

Government of the Republic of Lithuania (LRV). 2004-2011. Priorities of activity of government of the Republic of Lithuania [online], [cited 15 September 2012]. Available from Internet: http://www3.1rs.lt/pls/inter3/dokpaieska.showdoc_1?p_id=408916\&p_query=\&p_tr2=2

Karkatsoulis, P. 2010. The crisis effect on performance based budgeting, PAQ Winter: 449-478. Ministry of Finance of the Republic of Lithuania (FM). 2000-2011. Actual Financial Data [online], [cited 02 May 2012 ]. Available from Internet: http://www.finmin.lt/web/finmin/aktualus duomenys

Naraškevičiūtė, V. 2008. Savivaldybių biudžetų formavimo ir asignavimų naudojimo problemos Lietuvoje [Problems of minicipalities' budget formation and usage of assignations in Lithuania], Ekonomika ir vadyba [Economics and Management] 13: 149-156. 
Rakauskienè, G. O. 2006. Valstybès ekonomine politika [State economic policy]. Vilnius: Mykolo Romerio universiteto Leidybos centras. $772 \mathrm{p}$.

Rakauskienè, G. O.; Chlivickas, E. 2007. Public finance of Lithuania: gender perspective, Journal of Business Economics and Management 8(1): 11-27.

Shah, A. 2007. Budgeting and budgetary institution, by A. Shah (Ed.). The Worlds Bank. 525 p. Skačkauskienè, I. 2012. Valstybès ir savivaldybių biudžetu pajamos [The revenues of state and municipalities budgets]. Vilnius: Technika.124 p. http://dx.doi.org/10.3846/1282-S

Stanikūnas, R. 2010. Valdžios kišimasis ị rinką ir jo poveikis konkurencijai [Market intervention and its impact on competition], Pinigu studijos [Monetary studies] 1: 5-15.

Statistical Yearbook of Lithuania 2000-2011. Vilnius: The Lithuanian Department of Statistics [online], [cited 05 August 2012]. Available from Internet: http://www.stat.gov.lt/uploads/ metrastis/1_LSM_2011_Lt.pdf

Stiglitz, J. 2009. The anatomy of murder: who killed America's economy?, Critical Review 21(2, 3): 1-8.

Ilona SKAČKAUSKIENĖ. Doctor of Social Sciences, Associate Professor, the Head of the Department of Social Economics and Management, Vilnius Gediminas Technical University. Research interests: taxation, tax modelling and evaluating, budgeting, social and economic development. 